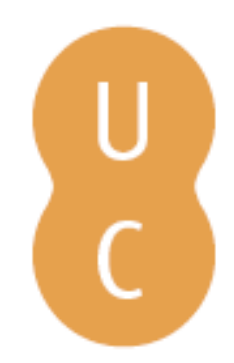

\title{
nombalina
}

\section{A retórica: disciplina de comunicação: una e múltipla, na sociedade e na escola}

Autor(es): $\quad$ Rei, José Nunes Esteves

Publicado por: Imprensa da Universidade de Coimbra

URL

persistente: URI:http://hdl.handle.net/10316.2/32020

DOI: $\quad$ DOI:http://dx.doi.org/10.14195/978-989-26-0498-5_15

Accessed : $\quad$ 26-Apr-2023 13:37:59

A navegação consulta e descarregamento dos títulos inseridos nas Bibliotecas Digitais UC Digitalis, UC Pombalina e UC Impactum, pressupõem a aceitação plena e sem reservas dos Termos e Condições de Uso destas Bibliotecas Digitais, disponíveis em https://digitalis.uc.pt/pt-pt/termos.

Conforme exposto nos referidos Termos e Condições de Uso, o descarregamento de títulos de acesso restrito requer uma licença válida de autorização devendo o utilizador aceder ao(s) documento(s) a partir de um endereço de IP da instituição detentora da supramencionada licença.

Ao utilizador é apenas permitido o descarregamento para uso pessoal, pelo que o emprego do(s) título(s) descarregado(s) para outro fim, designadamente comercial, carece de autorização do respetivo autor ou editor da obra.

Na medida em que todas as obras da UC Digitalis se encontram protegidas pelo Código do Direito de Autor e Direitos Conexos e demais legislação aplicável, toda a cópia, parcial ou total, deste documento, nos casos em que é legalmente admitida, deverá conter ou fazer-se acompanhar por este aviso. 


\title{
RHETORIC AND ARGUMENTATION IN THE BEGINNING OF THE XXIst CENTURY
}

\author{
EDITED BY
}

Henrique Jales Ribeiro
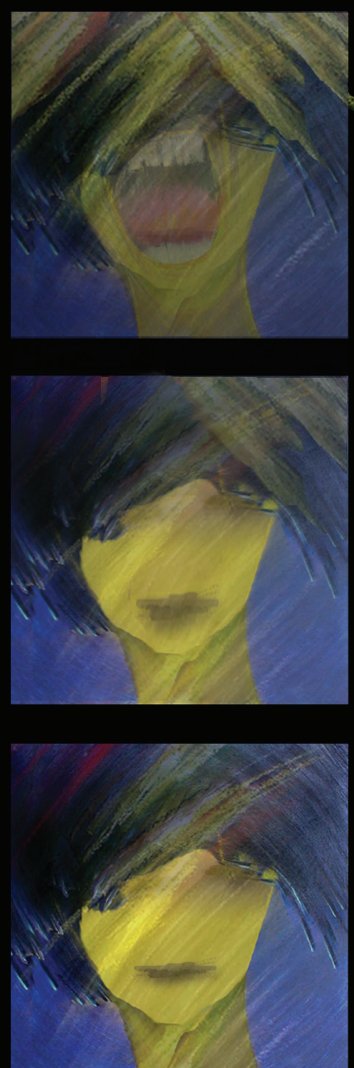
(Página deixada propositadamente em branco) 


\title{
RHETORIC AND ARGUMENTATION IN THE BEGINNING OF THE XXIst CENTURY
}

\author{
EDITED BY
}

Henrique Jales Ribeiro

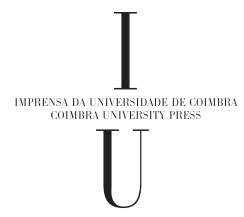

- COImbra 2009 
COORDENAÇÁO EDITORIAL

Imprensa da Universidade de Coimbra

Email: imprensauc@ci.uc.pt

URL: http://www.uc.pt/imprensa_uc

Vendas online: http://siglv.uc.pt/imprensa/

CONCEPÇÃO GRÁFICA

António Barros

CAPA

José Luís Madeira (IA / FLUC)

PRÉ-IMPRESSÁO

Paulo Oliveira

[PMP]

EXECUÇĂO GRÁFICA

Sereer, Soluçóes Editoriais

ISBN

978-989-8074-77-5

Depósito LEGAL

???????????????????????

OBRA PUBLICADA COM A COLABORAÇĀO DE:

\title{
FCT Fundação para a Ciência e a Tecnologia
}

MINISTÉRIO DA CIÊNCIA, TECNOLOGIA E ENSINO SUPERIOR Portugal

\author{
s \\ Ciência.Inovaçã̃o Programa Operacional Ciência e Inovação 2010 \\ 2010 MINISTÉRIO DA CIÊNCIA, TECNOLOGIA E ENSINO SUPERIOR \\ Unidade I\&D | Linguagem, Interpretação E Filosofia \\ ๑ JULHO 2009, IMPRENSA DA UNIVERSIDADE DE COIMBRA
}




\title{
CHAPTER I 5
}

\section{A RETÓRICA - DISCIPLINA DE COMUNICAÇÃO: UNA E MÚLTIPLA, NA SOCIEDADE E NA ESCOLA}

\author{
José Nunes Esteves Rei*
}

RESUMO: A Retórica apresenta-se, diacronicamente, envolvida em avanços e recuos, alargamento e diminuição de algumas das suas partes e, ainda, caracterizada como branca ou preta, morta ou ressuscitada. Haveria azo a perguntar: trata-se, ainda, da mesma ou de várias disciplinas? A ser única e com subdivisôes, interrogar-nos-emos: quais os fundamentos da sua compreensão?-Penso estarmos não só perante uma disciplina una, como diacronicamente em desenvolvimento quanto aos produtos discursivos e ao espaço social de intervenção, tornando-se cada vez mais complexa por confronto e exigência das sociedades que a solicitam, em cada nova Idade, e às quais responde positivamente, de acordo com as novas necessidades que se vão manifestando.-Como pressuposto, temos que a Retórica se tem apresentado como "didáctica dos discursos", uma "teoria do texto", termo esse que Van Dijk preferiria a esta expressão se não acontecesse, como refere, que "o conceito de retórica frequentemente se associa a determinadas formas e manifestaçóes estilísticas e de outra índole, em especial na comunicaçáo pública e persuasiva." (Van Dijk 1992: 19)-Estamos, assim, perante uma disciplina de comunicação discursiva, que se multiplica por espaços e tempos diferentes, num movimento pendular entre a sociedade, onde tem o seu espaço de autenticidade e eficácia, a escola, onde é objecto de tratados múltiplos, por parte de académicos, e a aprendizagem, do lado dos escolares.-A Retórica estrutura-se, assim, entre Sociedades, que a ela recorrem sob formas várias, tratados retóricos, que lhe traçam os correspondentes rostos, e Escolas, que os recebem e os transmitem de geraçóes em geraçóes, na preparação dos escolares para a vida activa.-Este triângulo retórico: Sociedade - Retórica - Escola, constituído instrumento de investigaçáo, permite estabelecer critérios, apontando três retóricas que se tornam concomitantes

\footnotetext{
* Universidade de Trás-os-Montes e Alto Douro, Departamento de Letras, Apartado 1013, 5001-801 Vila Real, Portugal.

E-mail: jrei@utad.pt
} 
após o surgimento sucessivo da segunda e da terceira.-Trata-se da Retórica clássica, antiga ou da inventio, localizada nos tribunais, e que mantém a sua actualidade desde a Grécia e Roma até aos nossos dias; da Retórica literário-cultural, romântica ou da elocutio, situada na governaçáo do Estado moderno e institucionalizada na literatura, que se expande a partir do século XVI e mantém, até hoje, a sua vitalidade; e da Retórica comunicativo-funcional, das empresas e organizaçóes ou da dispositio, surgida na segunda metade do século XX, que dá os seus primeiros passos em termos tratadísticos, reflexivos e escolares.

\section{A ABRIR: DIVERSIDADE DE USOS E DISCURSOS}

Se um grego clássico visitasse o nosso mundo político, jurídico, académico, social e empresarial, que sentiria perante o espaço aí ocupado pela Retórica: termo e seu uso prolixo, disciplina e seu conteúdo disperso? Surpresa e perplexidade, provavelmente.

Vejamos exemplos de uso surpreendente do termo "retórica".

A Ministra da Educação, há dias, satisfeita ao ouvir o Presidente da República elogiar a transferência das competências para as autarquias, na área da educação [dizia que]: "Há muito tempo que há retórica sobre o assunto, sobre o alargamento das competências das autarquias em muitas matérias [...]" (Jornal de Notícias, 14 Ag., 2008).

Filomena Mónica (2007: 102) fala de uma "retórica analfabeta"; o embaixador Seixas da Costa, "da retórica que subsiste nas relaçôes Lisboa-Brasília" (Visão, 29 Dez., 2008); José Manuel Fernandes, de "retirar a retórica verbal conservando o conteúdo das respostas, na condensação de uma entrevista” (Público, 17 Mar., 2008); João Dias da Silva, da FNE, [d'] a retórica do discurso da autonomia» (Público, 20 Jan., 2008); João Cândido da Silva, "[d'] os truques de retórica" (Público, 23 Abr., 2006).

Torga (1995), por seu lado, fala de uma "comunicação [...] sem retórica possivel [...] a dum sino aldeão, que em meia dúzia de badaladas [...] anuncia [...] um nascimento ou uma morte."

Todavia, outras afirmaçóes históricas sobre a Retórica deixar-lhe-iam menor surpresa? Vejamos.

— "No séc. IV, Élio Donato, na sua Arte da Gramática, cria uma secção sobre as figuras [e] as normas para escrever correctamente passam a incluir os preceitos para escrever ornadamente. Deste modo, cria a primeira indefinição das fronteiras entre as artes." (Garavelli 1991: 46)

— Sobre a Idade Média: "A Idade Média apresenta-nos uma nova configuração das disciplinas do trivium ao decompor a retórica em várias artes [...]: a arte da versificação, ars poetriae, a arte da epistolografia, ars dictaminis, e a arte da pregação, ars predicandi. A Dialéctica [...] vai também ela ocupar espaços retóricos: transforma-se na técnica do debate, destinada a alcançar não a verdade, mas uma conclusão perante duas posiçóes contrárias, mas ambas plausíveis" (Garavelli 1991: 46).

- No século XVI: "A retórica foi amputada de três das suas partes, a inventio, a dispositio e a memoria [exportadas para a Dialéctica], tornando-se uma Retórica restrita à elocutio e à actio conforme pretendia Petrus Ramus, na sua obra Institutions Dialectiques de 1543" (Meyer 1999: 135). 
Em sentido oposto, vemos outros alargarem esse espaço à história e ao ensaio. A primeira viria já de Cícero (Wolff 1988: 95), seguida, entre nós, por João de Barros. O segundo seria avançado por Montaigne, que o delimita assim: "Quero que as coisas venham ao de cima e [...] encham a imaginação [...]. A linguagem de que gosto é uma linguagem simples e natural [...] fora de afectação e de regras, descozida [sic], audaciosa [...]; nem pedantesca nem fradesca, nem tribunalesca [...]." (Montaigne 1993: 85-87).

A Retórica liberta-se da tipologia imposta pela Idade Média e vê-se integrada na ciência civil, pelos "mais famosos pedagogos do século XVI", como "o auge da formação integral do homem" (Garavelli 1991: 51).

- Nos séculos XVII-XVIII, com Vico (Gravelli 1991: 54), mas sobretudo no século XIX, com os românticos, ela receberá a missão de educar o povo (Barros e Murta s. d.: 26-28).

- E, no século XIX, ouvimos o grito de "guerra à retórica" lançado por Victor Hugo, sob a bandeira da sinceridade do autor, da sua intenção pedagógica e no respeito pelo código da língua (Olivier Reboul 1991: 90-91).

- Já no século XX, fala-se do regresso da Retórica depois de um "longo eclipse", como refere Olivier Reboul, de "Nova Retórica" (Perelman e Olbrechts-Tyteca 1988) e de "retórica [que] renasce das cinzas", nas palavras de Jean Paulhan (Belaval 1988: 34).

\section{O TERMO, A NOÇÁO E A DISCIPLINA}

De que falamos ao usar a palavra Retórica? Qual a sua função e o seu conteúdo? Para além dos sete objectivos de Michel Meyer (1998: 22), o nosso conceito de retórica é devedor de Yvon Belaval (1988: 53), em Digressions sur la rhétorique, ao afirmar: "Designemo-la - não ouso dizer: definir - como uma busca ponderada e [...] experimental sobre os meios da expressão, com vista a um fim prático" [s.n.].

Acreditamos na existência de uma unidade estrutural nas diferentes acepçóes de retórica: uma "negociação da distância entre os homens a propósito de uma questão, de um problema" - como para Michel Meyer (1998: 27) e "fruto da experiência milenar do diálogo e formulação das leis deste" - na expressão de Marc Fumaroli (1988: 16).

Parece, assim, claro que a Retórica sempre foi o espaço milenar da comunicação, do "diálogo" (Fumaroli 1988), da "negociação" (Meyer 1998) e dos "meios de expressão" (Belaval 1988).

Contrasta com esta diversidade de discursos, a perenidade da retórica, uma disciplina milenar, reconhecida por todos. E o que é uma disciplina? O termo disciplina, espalha-se no final do século XIX, em substituição de "matéria" ou "assunto" escolares. Ora, a sua determinação nocional parece decorrer da função que o conteúdo curricular desempenha na formação do aluno.

Perdeu-se a ligação do substantivo, disciplina, ao verbo, disciplinar: a mente, o corpo, o conhecimento e a sua arrumação. De outro modo, aí reconheceríamos a "disciplinação" mental, conteudística e expressiva para a comunicação. Avivar o elo conceptual "disciplina" / "disciplinar" é vital para compreender e justificar as matérias escolares. 
Roland Barthes, em 1964, elabora um Memorando sobre Retórica Antiga, para compreender a unidade da Retórica. Sente necessidade de "um livro, um manual, um memento, fosse ele qual fosse, que apresentasse um panorama cronológico e sistemático dessa Retórica antiga e clássica” (Barthes 1987: 19).

Com o objectivo de superar os discursos díspares sobre a Retórica e de medir a sua unidade, recorremos ao triângulo retórico: Sociedade - Retórica - Escola. A observação e a análise feitas, a partir destes ângulos ou categorias, permitem organizar, diacronicamente, a diversidade retórica numa perspectiva crescente e unificada. Oferecem um ganho de racionalidade e coerência nas mutaçôes sofridas pela disciplina, colocando a Sociedade como determinante das alteraçóes sofridas na Retórica e na Escola.

Temos como pressupostos, os seguintes:

1- A sociedade vai complexificando as relaçóes interpessoais e institucionais;

2- O seu devir histórico solicita novas formas de comunicação e seus correspondentes tratados;

3- Anteriores e recentes formas de comunicação ou retóricas mantêm-se em concomitância;

4- As mudanças verificadas na Sociedade e as correspondentes formas discursivas reflectem-se na Escola, com um atraso significativo, como se observa ainda hoje.

\section{O TRIÂNGULO RETÓRICO: INSTRUMENTO DE OBSERVAÇÃO E ANÁLISE}

A organização das palavras em discurso sempre foi uma actividade complexa, mas indispensável à sociedade. Sempre exigiu o esforço de ensino-aprendizagem, ancorado no encontro escolar entre um cliente/discípulo e um profissional/mestre. $\mathrm{O}$ conhecimento aí presente toma a forma de compêndio retórico, e, assim, surge o triângulo: Sociedade - Retórica - Escola. A primeira coloca permanentes desafios à língua; as respostas discursivo-textuais vão sendo sistematizadas e teorizadas em tratados; a escola considera-os indispensáveis. Matriz deste processo pode ser a Retórica a Herénio, manual atribuído a Cícero durante muito tempo.

Aplicado ao território da nossa disciplina, o triângulo descrito receberia três configuraçóes retóricas, correspondendo a espaços e funçóes sociais distintas: a clássica, antiga ou da inventio; a literaturizada (Barili 1985: 87), literário-cultural ou da elocutio; e a comunicativo-funcional, profissional ou da dispositio. Florescem na Antiguidade Clássica, do Renascimento ao século XIX, e na segunda metade do século XX, respectivamente, sendo os seus espaços, pela mesma ordem: o tribunal e o fórum; a ilustração, formação e acção do funcionário do Estado; as empresas, organizaçóes e instituiçóes.

Observemos as relaçóes que se estabelecem entre as duas primeiras, deixando de lado as de ambas com a terceira.

\section{QUE RELAÇÃO SOCIEDADE - RETÓRICA: ANTIGA, CLÁSSICA OU DA “INVENTIO”?}

A narrativa matricial do nascimento desta retórica mostra uma sociedade carenciada de organização, normas e leis. Vejamos. 
A Retórica nasceu de processos de propriedade. Cerca de 485 a. C., dois tiranos sicilianos, Gelão e Hierão, efectuaram deportaçóes, transferências de população e expropriaçóes, para povoar Siracusa e lotear os mercenários; quando foram depostos por uma sublevação democrática e se quis voltar à ante qua, houve processos inumeráveis, pois os direitos da propriedade eram pouco claros. Estes processos eram de um novo tipo: mobilizavam grandes júris populares, diante dos quais, para os convencer, era necessário "ser eloquente" [...]. Esta eloquência constituiu-se rapidamente em objecto de ensino. (Barthes 1960 e 1987: 23)

A caracterização da Sociedade grega, berço da Retórica clássica, destaca o facto de os Gregos, independentemente do regime político - democracia directa, aristocracia, oligarquia ou tirania - gostarem de "dirigir os seus assuntos públicos" (Kitto 1970: 174); gostarem "de actuar em grupo, em parte, porque queriam participar nos acontecimentos, em parte, porque gostavam da emulação" (Kitto 1970: 176).

É indispensável ter presente o que representa a polis na cultura grega, para compreendermos o gosto, o entusiasmo e a obrigação de todo o cidadão nela participar. $\mathrm{Na}$ expressão de Kitto, a polis era mais do que a unidade política, era "mais do que um Estado, uma nação ou um povo: [era] um sistema de vida [...], uma entidade [...] que exercitava o espírito e o carácter dos cidadãos. [Uma super-família que dava] plenitude e significado à vida" (Kitto 1970: 123-124, 206) .

Essa participação cívica exercia-se pela participação em duas instâncias, definidoras da Sociedade grega: a democracia e justiça, entre si relacionadas. A primeira era entendida como "a participação no governo da cidade de todos os cidadãos" (Kitto 1970: 207). Quanto à segunda, no século V, são milhares os cidadãos indigitados como juízes para o exercício da justiça (Mossé \& Schnapp-Gourbeillon 1994: 252). Mais, na inexistência de advogados de profissão, "uma pessoa lesada apelava directamente para os seus concidadãos, para que fosse feita justiça [...]. O júri popular era juiz de direito e de facto, e não havia apelação. [...] O promotor, se ganhava o caso, propunha uma pena, o acusado apresentava uma alternativa e o júri tinha de escolher uma das duas." (Kitto 1970: 211-212)

Que Retórica solicita essa Sociedade? Antes de lembrarmos a acção determinante de Aristóteles sobre a disciplina, vejamos o titubear dos seus primeiros passos.

Roland Barthes (1987: 19-91) refere uma oposição entre uma retórica sintagmática, discursiva, composta pelas partes da oratio, instituídas por Corax, no início do século V: o exórdio, a narração ou acção (relato dos factos), a argumentação ou prova, a digressão e o epílogo (Barthes 1987: 32), e uma retórica paradigmática, assente no trabalho sobre "as figuras" e aberta à "estilística".

A primeira está ligada à reivindicação da propriedade e situa-se "ao nível do conflito social [surgindo, assim,] um primeiro esboço teórico da palavra fingida (diferente da palavra fictiva, a dos poetas [...]" (Barthes 1987: 24-25). A segunda é criada por Górgias de Lentini, ao norte de Siracusa, que introduz a prosa no código retórico, "acreditando-a como sábio discurso, objecto estético, 'linguagem soberana', antepassado da 'literatura" (ib.). Trata-se "do surgimento de uma prosa decorativa, de uma prosa-espectáculo" (ib.), pela passagem dos Elogios Fúnebres, primeiramente compostos em verso, à prosa, sendo confiados a homens de Estado 
e nascendo, deste modo, um terceiro género (depois do judicial e do deliberativo), o epidíctico.

Foi enorme a acção de Aristóteles sobre a retórica clássica, dirigindo-se em três sentidos: a concepção, a função e a sistematização. A sua technè rhétorikè é caracterizada por Barthes como sendo "uma arte da comunicação quotidiana, do discurso em público" e como tendo por objectivo "regular a progressão do discurso, de ideia em ideia”. À retórica compete, na expressão aristotélica, "descobrir especulativamente o que em cada caso, possa ser próprio para persuadir" (Retórica, 1355 b 25-26, e 1356 a $19-20)$.

Quanto à função, Aristóteles, ao reduzir-lhe o poder à busca dos meios de persuasão em cada caso concreto, “torna-a mais plausível e mais eficaz. Entre o 'tudo' dos sofistas e o 'nada' de Platão, a retórica [com Aristóteles] contenta-se com ser qualquer coisa, mas de um valor certo", na expressão de Olivier Reboul (1991: 38). Mais, a função da retórica é, assim, a de "defender argumentando, em situaçóes em que a demonstração não é possível, o que lhe impóe passar por 'noçôes comuns' que não são opiniốes vulgares, mas aquilo que cada um pode encontrar pelo seu bom senso, em domínios nos quais nada seria menos científico do que exigir respostas científicas" (Reboul 1991: 38).

A sistematização compreende "uma teoria da argumentação que constitui o eixo principal e que fornece simultaneamente o nó da sua articulação com a lógica demonstrativa e com a filosofia [...], uma teoria da elocução e uma teoria da composição do discurso" (Ricoeur s. d.: 13).

\section{QUE ESPECIFICIDADE NA RELAÇÃO SOCIEDADE - RETÓRICA: LITERÁRIO CULTURAL OU DA “ELOCUTIO”?}

É no século XVI que esta se desenvolve e consagra, por a Sociedade apresentar novos elementos que a solicitam. A sua narrativa etiológica é de Cícero, na abertura da Retórica ou da Invenção Oratória.

Houve um tempo em que os homens erravam pelos campos como os animais [...]: a força decidia tudo. [...] Não tinham qualquer ideia de deveres para com a Divindade nem para com os seus semelhantes [...]. As paixóes cegas e brutais subjugavam o espírito [...]. Nesses tempos de barbárie, um homem descobre em si uma sabedoria e uma força superiores.

À sua voz, os homens [...] juntam-se e reúnem-se numa clareira. Esse homem inspira todos os gostos honestos e úteis a esses corações ferozes [...], num primeiro momento, querem rejeitar um jugo cuja novidade os revolta, mas [...] sensíveis à eloquência da sabedoria, tornam-se finalmente humanos e civilizados quando antes eram selvagens e bárbaros (Cicéron 1848: Liv. 1º, p. II).

\section{A) O século XVI}

Determinantes na caracterização das novas valências da Sociedade no Século XVI foram: o surgimento do Estado, a figura do cortesão e a explosão dos colégios, como estratégia da Reforma e da Contra-Reforma. 
O Estado desenvolve-se apoiado em duas figuras, pilares da abundância e da riqueza, saídas do mercantilismo, cada vez mais a nível mundial (Godinho 1963: 11): o nobre e o burguês. Através delas, multiplicam-se os oficiais do rei tanto na governação central como na administração provincial e colonial: desde a cobrança de impostos à administração da justiça e ao serviço no exército.

Este capitalismo comercial, iniciado no século XVI na Itália e continuado depois pelas naçôes ibéricas, mantém "os traços essenciais de [...] uma sociedade aristocrática que encontra a sua forma de expressão no regime senhorial” (Touchard 1970: 9). Desenvolve-se, assim, "uma teoria, a do abolutismo [...] sem limites e sem contrôle" (Touchard 1970: 10).

Numa sociedade com esta concepção de poder, parece não restar espaço para o exercício do livre-arbítrio, da opiniẫo e da discussão, entrevendo-se já o desenvolvimento do campo da conotação, da ficção ou da "representação do mundo", mais tarde referenciado pelo termo "literatura".

Em contraste com esta diminuição da expressão individual crescem as possibilidades de divulgação dos escritos através da folha impressa, indo da divulgação dos textos antigos, religiosos ou náo, à dos grandes humanistas.

"As [obras] de Erasmo terão tiragens de várias centenas de milhares de exemplares, no decorrer do século XVI." (Corvisier 1977: 50-51) A Igreja e os soberanos exercem uma cerrada vigilância sobre a imprensa, sendo a censura, em geral, entregue às universidades - tornadas centro da indústria do livro e pólos de cultura.

De Itália vem, ainda, um novo tipo de homem, o cortesão, cujo ideal Baldassare Castiglione (1478-1529) consagrou. Quem é esta figura? "Um homem senhor de si, de elegância comedida, afável e educado [...], instruído e cuja conversação está isenta de pedantismo e grosseria." (Corvisier 1977: 56)

Em 1537, chegam a Roma os inacianos. Estabelecem laços pessoais com o Papa e constituem-se "em grupo de reformistas que o poder romano observa com um misto de curiosidade e de admiração" (Corvisier 1977: 105). A 27 de Setembro de 1540, nascia a Companhia de Jesus.

Na primeira metade do século XVI, toda a Europa foi varrida por uma onda de colégios, a maior parte deles municipais, cujos corpos directivos eram recrutados de entre "humanistas errantes muitas vezes influenciados pelas 'novidades luteranas" (Mesnard s. d., p. 63). Estamos, assim, perante uma consolidação da Reforma.

Traçada a rota da acção contra-reformadora e guardando boas recordaçóes do seu estudo em Paris, é para lá que o primeiro Geral envia os seus estudantes, tornando-os "letrados, para pregar e confessar" (Mesnard s. d.: 66), ou seja, para o exercício da palavra, em público e em privado.

Qual o papel reservado à Retórica, nesta sociedade do século XVI? Sobretudo o de agente de mudança. A busca da verdade torna-se numa aguda questão individual, deixando de lado o caminho da disputatio medieval e optando pela laboriosa conquista pessoal (Garavelli 1991: 51). A Retórica liberta-se da tipologia imposta pela Idade Média, ouve o apelo ao desenvolvimento da elocutio, isto é, da expressão, e, sobretudo, vê-se integrada na ciência civil, representando "o auge da formação integral do homem" (ib.). De facto, ela vai estar na origem de uma das maiores revoluçóes culturais do Ocidente - a literário-pedagógico-didáctica, tendencialmente alargada às massas (Garavelli 1991: 54). 
Torna-se no palco de representação-acção do orador e do literato-intelectualescritor. Este abraça a língua nacional, nela desenvolve os géneros escritos em prosa e quer ser ouvido por reis e súbditos, a quem pretende "agradar, instruindo" (Ménager 1968: 24-28).

Esta segunda retórica, literário-cultural, situa-se para além das necessidades do indivíduo, dos actores e dos lugares retóricos tradicionais: enxerta-se no espaço da cultura que, por sua vez, presta um relevante serviço à política.

Assim o entende Eugénio Garin (1972: 72, 93) quando afirma: "A cultura é uma componente importante da política [...], é um instrumento precioso para viver e brilhar nas novas cortes, [...] para progredir na carreira, para assumir cargos militares."

São três os factores determinantes desta mudança:

- a deslocação da cultura das universidades e dos mosteiros para um público mais vasto, "nas cortes , [...] palácios comunais, residências burguesas [...] suscitando formas diferentes de comunicação" (Garin 1972: 71);

- a vulgarização da língua nacional por filósofos, escritores e historiadores, escrevendo alguns "ao mesmo tempo em Latim e em volgare" (Garin 1972: 71-72);

- por último, a rápida expansão da imprensa, que "favorecia a coroação do renascimento" (Garin 1972: 74).

B) Do século XVII ao século XIX

$\mathrm{Na}$ análise da Sociedade deste período, são relevantes as actividades políticas e económicas - absolutismo, desenvolvimento e classes dirigentes - bem como as actividades pedagógicas e culturais - as escolas, confessionais e públicas, as academias e os cafés.

O poder passa de regime absoluto a regime liberal e a atitude do povo, de abúlica a interventiva, em particular, a dos jovens universitários do início do século XIX, apegados ao ideário liberal, com caução inglesa.

O século XVIII traz um surto desenvolvimentista, devido ao ouro do Brasil e à organização "das forças económicas [direccionadas pelo Estado] para a produção e o comércio vinícola" (Saraiva 1983: 397). Entretanto, com as obras públicas, o país apresenta, no final do século, uma balança comercial positiva.

Assiste-se a uma renovação das classes dirigentes que só termina depois do vintismo do século XIX. Na sua origem, encontram-se a progressiva complexidade das funçóes do Estado e o florescimento de uma classe média, fruto da acção educativa dos colégios, marcada por uma alteração de mentalidade, e da mudança na composição das classes dirigentes. Por outro lado, desde o tempo do Marquês de Pombal, "o sangue nobre deixou de ser suficiente para o exercício de funçóes públicas, civis ou militares" (Saraiva 1983: 398).

A viragem cultural do início do século XVIII muito deve a instituiçóes relevantes como as academias e os cafés. A origem das primeiras pode situar-se "no interesse pela discussão das coisas do espírito" (Pereira 1983: 351), permitindo o contacto com os livros e o estudo. Os segundos chegam com Pombal, na altura da reconstrução de Lisboa, quando botequins e cafés se expandem, pretendendo o seu reconstrutor, assim, "equiparar a cidade às outras capitais" (Pereira 1983: 351).

Os cafés ganham importância pela sua ligação à vida artística, à vida literária e à política. Neles, "os poetas como Bocage logravam admiradores e imitadores 
mais numerosos e entusiastas" do que nas velhas academias domésticas e partidas, "adaptando-se a um gosto mais popular e [cantando] aspiraçóes modernas. O poeta, enfim, descia à rua." (Pereira 1983: 351)

Joel Serrão afirma mesmo que "o Botequim das Parras festejou e pode dizer-se que contribuiu para preparar a revolução de 1820" (Serrão 1988: 167). Um outro, onde se desenrolou actividade política significativa, foi o Marrare, do italiano António Marrare, que em Lisboa reformou vários destes estabelecimentos: "Lá se preparou e celebrou a Regeneração. Lá fazia propaganda maçónica Passos Manuel. A tal ponto que o $2^{\circ}$ Conde do Lavradio chegou a afirmar que Portugal estava sendo governado pelos cafés." (Serrão 1971)

Nos séculos XVII e XVIII, a retórica da expressão privilegia a inteligência, subjacente à alegria de pensar, ao prazer de oferecer aos outros aquilo que se compreende bem. A teorização desta retórica da expressáo da inteligência nasce entre os oratorianos, com os Padres Lamy, Thomassin e Rollin.

Entre nós, é Luís António Verney quem levará mais longe o esforço de renovação da retórica. Qual a sua ideia sobre ela? Uma disciplina presente em todas as formas de expressão, oral ou escrita, cobrindo todo o espaço da comunicação do homem. Está ao serviço da clareza do pensamento e da simplicidade da expressão.

No século XIX, surge uma componente realista da retórica, ao serviço do compromisso social e político, na busca de uma sociedade nova, mais justa e mais livre que a do antigo regime. Socialistas utópicos, românticos liberais, progressistas com as mais diversas origens, acreditam, a partir dos ideais liberais da revolução francesa, na nova ordem social e política, na nova arte, capaz de a exprimir.

Teorizador e criativo desta arte realista, entre nós, foi Almeida Garrett, para quem a missão da arte é transportar a verdade da história, da sociedade, do povo, e "a literatura é a expressão da sociedade" (Saraiva 1961: 57-59). Segundo ele, à indefinição do futuro da literatura não é alheia a indefinição do futuro da sociedade: "a literatura actual é o verbo ainda balbuciante de uma sociedade indefinida" (Saraiva 1961: 57-59).

Na sua teoria literária, Garrett concebe uma verdade objectiva e atribui ao escritor a missão de a comunicar ao povo: "derramar pelas nações um ensino fácil, uma instrução intelectual e moral que [...] surpreenda os ânimos [...] no meio dos próprios passatempos, eis a missão do literato, do poeta." (Barros e Murta s.d.: 27)

A retórica da expressão romântica realizou ainda a "revolução que derrubou o 'antigo regime' da língua”, na expressão forte de V. Hugo (Lanson 1912: 942-943), adaptando à transmissão do sentimento e da sensação uma língua, até aí, ao serviço das ideias, da filosofia, das academias e dos serviços públicos.

Esta retórica pretendia, assim, aceder à verdade e à vida do homem individual, pela demolição das "leis do gosto [de alguns], das regras dos géneros, sua divisão e convenção [...]" (Lanson 1912: 939). Com ela, a prosa artística deixa de ser "uma prosa exacta, lógica, perfeitamente inteligível” e torna-se "[n] uma prosa que [...] contém [...] todas as virtudes essenciais da música, da pintura e do verso" (Lanson 1912: 223) e desloca a frase da ordem intelectual para a ordem estética. Mais, esta prosa instala-se "até nos manuais escolares, até nos jornais, até nos discursos parlamentares" (Lanson 1912: 223). 
Conhecemos o papel de Garrett, Herculano, Camilo e, sobretudo, de Eça de Queirós, como obreiros dessa revolução da língua ou do "antigo regime” da língua. Como refere Guerra da Cal: "Antes deles, [ela] era ainda a linguagem dos clássicos dos séculos XVI e XVII: um instrumento rico, hierático, rígido e solene [...] com uma sintaxe aferrolhada por regras inflexíveis [...], uma língua [...] petrificada [...] inadequada para a expressão viva dos matizes da inteligência e da emoção suscitados por novos estilos de vida [...].” (Cal 1981: 57)

\section{QUE RELAÇÃO SOCIEDADE - RETÓRICA: COMUNICATIVO-FUNCIONAL, PROFISSIONAL OU DA “DISPOSITIO”?}

A narrativa que pode revelar a sua justificação, a partir de valências emergentes na Sociedade, inicia a obra Estrutura e Dinâmica das Organizaçóes de Henry Mintzberg.

A Sra Raku tinha um estúdio de cerâmica na cave da sua casa, em Nova Iorque. Encarregava-se ela mesma de todas as tarefas: preparação do barro, moldar os potes, preparar e aplicar os vidrados e cozedura no forno. A ambição e sucesso criaram um problema: a oferta não chegava para as encomendas. Contactou a vizinha e dividiu as tarefas entre ambas, sendo a comunicação informal suficiente.

Todavia, as encomendas aumentaram e o pessoal começou a crescer, havendo necessidade de aumentar espaço, especializar pessoas, cuidar da satisfação dos públicos, enfim, constituir uma empresa, com dois fortes vectores, um interno e outro externo."

Nesse momento, a comunicação formaliza-se e teve mesmo de a entregar a profissionais que a dominasse nas diferentes versóes: interna e externa, publicitária e de crise, pública e interpessoal, atendimento e negociação, social e institucional (Mintzberg 1995: 19).

A sociedade do século XX inclui entre as suas marcas mais definidoras, a imprensa, a publicidade e a comunicaçáo institucional, marcando-o como o século da comunicação. Se a implantação pragmática destas formas de comunicação na sociedade é um dado adquirido, a sua introdução no espaço da língua, pela teorização específica sobre as suas práticas, tem sido objecto de natural resistência.

Dizer que vivemos numa sociedade de comunicação é hoje um lugar-comum. Que factores determinam o seu desenvolvimento? Vejamos: 1) As aglomeraçóes urbanas concentram-se desmesuradamente, tornando difícil o conhecimento e as relaçóes entre as pessoas. 2) A actividade produtiva desloca-se para o sector terciário, dos serviços (Salinas e Tena 1992: 27), onde a língua é a principal ferramenta de trabalho. 3) A tecnologia oferece à informação condiçóes ímpares de escala, de rigor e de quantidade de indivíduos atingidos (Lempen 1980: 19). 4) Satisfeitas as necessidades essenciais, surge uma homogeneidade social e fica uma margem económica para o progresso da tecnologia e a comercialização dos bens de informação. 5) O nível de educação, relativamente elevado e generalizado, proporciona à informação um espaço social amplo para justificar o seu desenvolvimento. 
A generalidade dos indivíduos, sem a fé religiosa e as certezas ancestrais, "está mais disponível, mas também mais vulnerável. [...] já não possui escala de valores, reconhecida, para exercer livremente o seu espírito crítico, para orientar o seu comportamento. [...] é objecto de uma luta de influências por parte de poderes que procuram determinar o seu comportamento, passando de uma forma de condicionamento a uma outra." (Lempen 1980: 27)

Ficam a um passo da manipulação por toda uma série de meios de persuasáo que se encontram nas máos do poder político e económico, na cidade ou no campo, na fábrica ou no escritório. Neste contexto, a própria informação surge como o suporte de uma ideologia e um meio de propaganda ao serviço desses poderes. Também a informação e a ideologia aparecem num vazio religioso, axiológico e crítico: a primeira "impóe a realidade ao espírito, [a segunda] transforma a realidade segundo a orientação escolhida" (Lempen 1980: 19), conveniente e adequada aos interesses de quem a divulga ou segue.

A retórica solicitada pelas novas vertentes da sociedade do século XX começa a revelar a sua especificidade nos espaços da comunicaçáo social, publicidade e comunicação interna.

A especificidade desta retórica profissional na imprensa é sentida, desde o seu início: "estilo simples e correntio", referia, em Dezembro de 1663, o Dr. António de Sousa Macedo, director do segundo título surgido entre nós (Cruz 1983: 193).

A proximidade entre o parlamento e o jornalismo é sublinhada por Francisco Ayala (1985: 51), que identifica, no jornalismo, as 553 máximas presentes na Lógica Parlamentar, de W. G. Hamilton. Os discursos de um e de outro pretendem resultados práticos, na sensibilidade e na inteligência: mover o destinatário da mensagem em determinada direcção. Das qualidades retóricas sobressai a concisão, visando a atenção dos receptores e a economia do papel.

No que diz respeito às informaçóes, a sua redacção apresenta a forma mais concreta possível. O contraste é enorme. Como refere Ayala (1985: 53), "[antes] a expressão gramatical correcta era questão de cortesia e urbanidade"; hoje, para ganhar espaço, estilo telegráfico e a perda do respeito pela gramática e pelos leitores tomaram as notícias. A ignorância não permite dar a conhecer aquilo que o bom jornalista sabe $\mathrm{e}$ a notícia, como o texto publicitário, é redigida de modo a agarrar o leitor.

Na caracterização da chamada "má retórica", Ayala (1985: 51, 63) menciona: os verbos de encher, as frases feitas, de carácter eufemístico ou de sentido hiperbólico, sem falar da "não retórica", caracterizada "pelo descuido, debilidade e rudeza expressivas." Em crescendo, está o estudo e a teorização destas produçóes, no âmbito de vários ramos das Ciências da Comunicação.

A especificidade da retórica profissional na publicidade teve o seu precursor em Émile de Gardin, o grande renovador dos textos publicitários, num artigo de 22 de Abril de 1845, no seu jornal La Presse, ao pressupor uma nova concepção do anúncio e ao substituir o estilo de redacção antigo pela modalidade de reclamo simples, breve e vendedor. Afirma: "Muitos comerciantes crêem fazer ao mesmo tempo um acto de habilidade e de próprio benefício, dissimulando os anúncios de maneira que pareçam artigos escritos [...]; o anúncio deve ser conciso, simples e franco; nunca aparecer mascarado; ir directo ao objectivo com a cabeça levantada [...]. Todo o comentário 
adicional, se não é nocivo, é, pelo menos, supérfluo. Todo o elogio em vez de provocar confiança, provoca a incredulidade.” (Gúzman 1989: 136)

Com o final do século XIX, chega ao seu termo o aperfeiçoamento da chamada publicidade informativa-persuasiva, correspondendo à época da psicologia pré-científica. Ao tomar o consumidor como um indivíduo de bom senso e consciente, utiliza os elementos contidos na célebre sigla AIDA (Atenção, Interesse, Desejo e Acção) como base da criação dos textos publicitários (Gúzman 1989: 152).

A partir de 1940, a agência americana Ted Bates and Company, com a sigla USP (“Unique Selling Proposition”: Proposição Única de Venda), trouxe um forte contributo para o mundo publicitário. Partindo do conceito de "poder de convicção", veiculado por um anúncio, esta teoria apoia-se na concepção racional da personalidade humana, que a leva a procurar um benefício concreto no uso ou consumo dos produtos comprados. Deste modo, a publicidade deve descobrir a melhor mensagem, única, que permita oferecer benefícios concretos ao consumidor, escolhendo a melhor característica do produto e nela baseando as suas argumentaçóes.

Nos anos cinquenta, partindo de grandes investigaçôes feitas na área da motivação, a técnica publicitária sofre uma autêntica revolução. Em 1957, Pierre Martineau, director de investigaçáo do Chicago Tribune, lança uma nova forma de criar as mensagens com base nos dados vindos da investigaçáo motivacional: era a forma da criação da "imagem do produto”. A publicidade muda de rumo, a sua bússola passa a apontar para outro norte: "já náo consiste em provar e destacar a superioridade de tal produto frente aos outros, mas proporcionar ao público um sentimento ligado ao produto, de modo que o leve a desejá-lo.” (Gúzman 1989: 157)

O texto do anúncio deixa de apontar para a eficácia, deslocando o seu alvo para o mundo simbólico e imaginário que, juntamente com a imagem, é chamado a construir. Um produto será comprado pelo que significa para o indivíduo, "dentro do seu conjunto de atitudes, hábitos e motivaçóes. O acto de compra é, como toda a conduta humana, uma forma de auto-expressão na qual se procura comunicar aos outros o que cada indivíduo pensa que é (Gúzman 1989: 157-158). Nos anos setenta, com o despertar da consciência dos consumidores, a publicidade começará a ser concebida, mais do que como técnica comercial, como uma forma de comunicação.

Comunicativa é a dinâmica que envolve a publicidade das últimas décadas; imaginário é o conteúdo da mensagem aposta aos produtos, serviços, bens ou pessoas; axiológica é a mais-valia por ela acrescentada a tudo o que vende; e arbitrária é a relaçáo entre esse valor acrescentado e o seu suporte, objecto de venda e de compra. É o tempo em que “as marcas se tornam 'pessoas”, em que "é necessário dar uma 'alma' a uma marca” e em que 'a qualidade' vai transformar-se num 'valor'” (Séguela 1991). É hoje claro que "é [...] função da publicidade destacar a diferença, chamar a atenção, surpreender, seduzir através de um valor imaginário acrescentado" (Brochand 1988: 15). A nova publicidade vai, assim, ser "um grande espectáculo, tornado uma arte única" e exclusiva, produtor de um grande prazer, e, ainda, "a expressão popular de uma ética, de um sistema de valores, de uma moral, muito simplesmente, de uma cultura" (Brochand 1988: 15).

A especificidade da retórica profissional na comunicação interna merece a maior atenção nas empresas e organizaçóes, pelo relevo crescente aí adquirido e pelo número de indivíduos nela implicados. Inclui escritos de acção institucional cuja simples 
existência marca uma posição ou um compromisso na empresa ou organização, sendo secundarizado o seu conteúdo. É que, ao ser vertido em dado tipo de texto, está de imediato a circunscrever-se a certos temas, áreas e situaçóes que o usam e onde desempenha uma função institucional.

Tais escritos e a sua preparação solicitam reflexão teórica sobre a sua natureza, tipologia e funcionalidade, assim como uma formação específica, conduzindo ao domínio dessas práticas retóricas profissionais.

A retórica profissional tem as suas origens nas cartas, as quais, em Cícero, atingem uma perfeição que faz delas uma referência: da função que hão-de vir a desempenhar e do estilo que o autor lhes imprime. É o que reconhece Rollin desde o século XVIII, o século da epistolografia: "['A eloquência florida e brilhante'] pareceria ainda mais insuportável nas cartas, cuja simplicidade constitui a sua principal marca [...]. Cícero é disso prova e pode, ele sozinho, servir-nos para nos formarmos em todo o género de eloquência. As suas cartas podem dar-nos uma ideia precisa do estilo epistolar.» (Rollin 1748: 128)

\section{CONCLUSÃO}

Para concluir, como sinal dos tempos, reconhecemos que, hoje, se fala mais do que se estuda a retórica. Todavia, ela está viva e recomenda-se. Apesar disso, os políticos desconhecem-na, os juízes não a têm nos seus "curricula", os jovens escritores desprezamna e os directores de comunicação empresarial passam-lhe ao lado.

Ou talvez as coisas não sejam assim. Do nosso ponto de vista, o juiz, o político, o escritor e o Dircom, director de comunicação, têm as suas retóricas próprias, a individualizar e a desenvolver nos respectivos territórios.

A sociedade vai dando sinais de como nela as coisas se passam. Ainda na semana passada, o Ministro da Cultura anunciava a reformulação do ensino da língua portuguesa no estrangeiro. E qual a razão? Afirmava: "porque muitos alunos 'não querem o português literário”" (Público, 29 Set., 2008, p. 9). Perguntemos: qual deles? O de Camóes e Vieira, clássico, ou o de Garrett e de Eça, moderno? Querem outro, a descobrir, curricularmente, onde?

Essa afirmação recorda-nos a de António José Saraiva (1960: 6) a 28 de Junho de 1960, em "As duas literaturas portuguesas", texto de O Primeiro de Janeiro, quando:

A literatura portuguesa moderna começa em meados do século XVIII com a prosa de Verney. [Da anterior] é outra a sua temática, outro, o seu estilo. [...]. [Depois] dir-se-ia que os escritores deixaram de saber escrever; perderam o sentido da economia dos recursos estilísticos; [...] são demasiado terra-a-terra, roçando pela brutalidade ou demasiado afectados. [...] Além disso deixou de haver padróes comuns; cada escritor é um país diferente. [...] É a partir do século XVIII que os centros regionais como Porto, Coimbra e Baia começam a ganhar importância na literatura.

Dessas três línguas, a reconhecer sem cotaçóes culturais, poderiam ser contraponto, na sociedade e na escola, as três retóricas de que falámos. 


\section{REFERÊNCIAS}

AYALA, Francisco (1985), "La Retórica del Periodismo", in La Retórica del Periodismo y otras Retóricas, Madrid: Editorial Espasa-Calpe.

BARILI, Renato (1985), Retórica, Lisboa: Editorial Presença.

BARROS, João de, e MURTA, Guerreiro (s. d.), Como se devem ler os escritores modernos, Lisboa: Livraria Sá da Costa.

BARTHES, Roland (1960), "A retórica antiga”, Communications, 16. Retomado em R. Barthes, A Aventura semiológica, Lisboa: Ediçôes 70, 1987.

_-_-_(1987), A Aventura semiológica, Lisboa: Ediçôes 70.

BELAVAL, Yvon (1988), Digressions sur la rhétorique, Paris: Ramsay.

BROCHAND, B. (1988), "L'Alchimie de la publicite", in B. Chatelat et R. Ebguy (éds.), Styles de Pub, 60 manières de communiquer, Paris: Les Éditions d'Organisation.

CAL, Ernesto G.. (1981), Lingua e estilo de Eça de Queiroz, 4a ed., Coimbra: Livraria Almedina.

CASTRO, Aníbal P. de (1973), Retórica e teorização literária em Portugal, Coimbra: Centro de Estudos Românicos.

CICERON (1848), "De l'Invention Oratoire", in Oeuvres Complètes, T. II, trad. M. Nisard, Paris: Du Bocholet, Le Chevalier Editeurs.

CORVISIER, André (1977), História Universal. O mundo moderno, Vol. III, $3^{\text {a }}$ ed., Lisboa: Círculo de Leitores.

CRUZ A., (1983), “As classes e os problemas da sociedade portuguesa”, in António José Saraiva (dir.), História de Portugal, Vol. V, Lisboa: Publicaçóes Alfa.

DIJK, Teun A. van (1992), La Ciencia del Texto, Barcelona et al.: Ediciones Paidós.

FUMAROLI, Marc (1988), "Préface", in Y. Belaval, Digressions sur la rhétorique, Paris: Ramsay.

____-(1999), Histoire de la Rhétorique dans l'Europe Moderne : 1450-1950, Paris: PUF.

GARAVELLI, Bice (1991), Manual de Retórica, Madrid: Ediciones Cátedra.

GARIN, Eugene (1972), O Renascimento. História de uma Revolução Cultural, Porto: Telos Editora.

GODINHO, Vitorino M. (1963), Os Descobrimentos e a Economia Mundial, Vol. I, Lisboa: Editorial Arcádia.

GÚZMAN, José R. S. (1989), Breve História de la Publicidad, Madrid: Editorial Ciência.

KITTO, H. (1970), Os Gregos, Coimbra: Arménio Amado.

LANSON, Gustave (1912), Histoire de la Littérature Française, Paris: Librairie Hachette.

-__-_(s. d.), L'Art de la Prose, $10^{\text {a }}$ ed., Paris: Librairie des Annales.

LEMPEN, Blaise (1980), Information et Pouvoir. Essais sur le sens de l'information et son enjeu politique, Lausanne: Éditions L'Age de l'Homme.

LEMPEREUR, Alain (ed.) (s. d.), Colloque de Cerisy. L'argumentation, Liège : Mardaga.

MENAGER, Daniel (1968), Introduction à la vie littéraire au XVIe Siècle, Paris: Bordas.

MESNARD, Pierre (s. d.), "A Pedagogia dos Jesuítas", in J. Chateau, Os Grandes Pedagogos, Lisboa: Livros do Brasil.

MEYER, Michel (dir.) (1999), Histoire de la Rhétorique, Paris: PUF, Le livre de poche.

-__-(1998), Questōes de retórica: Linguagem, razão, sedução, Lisboa: Edições 70.

MINTZBERG, Henry (1995), Estrutura e Dinâmica das Organizaçôes, Lisboa: Dom Quixote.

MÓNICA, Filomena (2007), Confissôes de uma Liberal, Famalicão: Quasi.

MONTAIGNE (1993), Três Ensaios, coord. de Agostinho da Silva, 2a ed., Lisboa: Vega.

PEREIRA, José C. (1983), "Vectores culturais portugueses de Seiscentos e Setecentos", in J. Saraiva (dir.), História de Portugal, Vol. V, Lisboa: Publicaçóes Alfa.

PERELMAN, Chaïm, et OLBRECHTS-TYTECA, Lucie (1988), Traité de L'Argumentation, 5 a ed., Bruxelles: Editions de l'Université de Bruxelles.

REBOUL, Olivier (1991), Introduction à la rhétorique, Paris: PUF. 
REI, José N. E. (1998), Retórica e Sociedade., Lisboa: IEE.

RICOEUR, P. (s. d.), A Metáfora Viva, Porto: Rés Editora.

ROLLIN, Charles (1748), De la manière d'enseigner et d'étudier les belles-lettres par rapport à l'esprit et au coeur, Vol. II, Paris: Chez la Veuve Estienne.

SALINAS, Fernando, e TENA, Rosário (1992), Información y Comunicación, los medios y su aplicación didáctica, 2a ed., México: Ediciones G. Gili.

SARAIVA, António J. (1960), "As duas literaturas portuguesas", Comércio do Porto, 28 Jun., p. 6.

____(1961), Para a História da Cultura em Portugal, Lisboa: Publicaçóes Europa-América. -(dir.) (1983), História de Portugal, Vol. V, Lisboa: Publicaçóes Alfa.

SÉGUELA, Joel (1991), "Entrevista", Público, 15 Out., p. 3.

SERRÃO, Joel (1971), Dicionário de História de Portugal, Lisboa: Iniciativas Editoriais.

(1988), Perspectives de la société portugaise du XIX siècle. Le XIXe Siècle au Portugal. Histoire - Société - Culture - Art. Actes du Colloque, Paris, 6-7-8 Novembre 1987, Paris: Fondation Calouste Gulbenkian, Centre Culturel Portugais.

TORGA, Miguel (1995), Diário, Vol. II, Coimbra: Gráfica de Coimbra.

TOUCHARD, Jean (1970), História das Ideias Políticas, Vol. III, Mem Martins: Publicações Europa-América.

WOLFF, Helène (1991), "Prose historique et rhétorique. Les Chroniques de Chastelain et Molinet", in S. Cigala et A. Slerca (éd.), Rhétorique et mise en prose au XVe siècle, Actes du VI Colloque International sur le Moyen Français, Milan, 4-6 mai 1988, Miláo: Vita e Pensiero. 

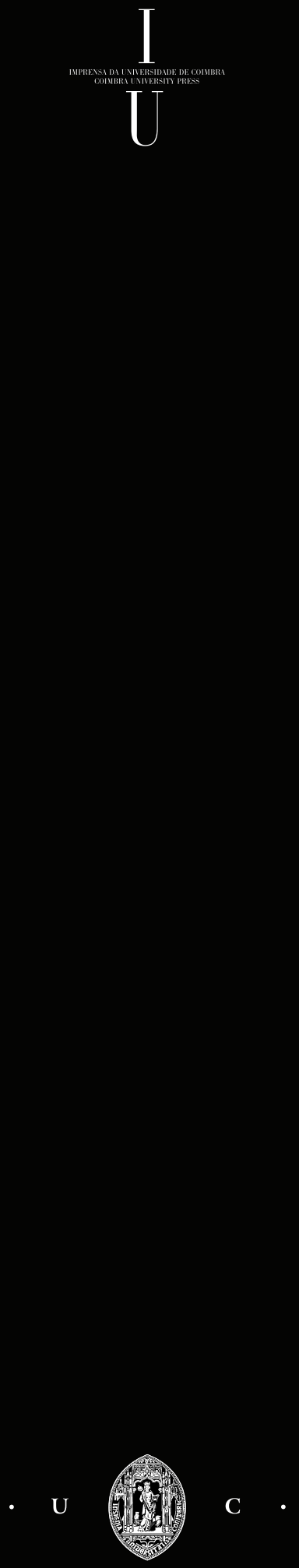